O. Aleksandrova ${ }^{1}$, Dr. Sc. (Ph.), Prof., orcid.org/0000-0003-0030-1367, L. Batchenko², Dr. Sc. (Econ.), Prof., orcid.org/0000-0001-6975-5813,

M. Dielini ${ }^{3}$, Cand. Sc. (Econ.), Assoc. Prof., orcid.org/0000-0001-5899-0818, U. Lavryk ${ }^{1}$, Cand. Sc. (Econ.), orcid.org/0000-0001-8772-4690
1 - Borys Grinchenko Kyiv University, Kyiv, Ukraine, e-mail: olena.aleksandrova@yahoo.com; u.lavryk@kubg.edu.ua 2 - Kyiv National University of Culture and Arts, Kyiv, Ukraine, e-mail: ludavic@meta.ua

3 - National Pedagogic Dragomanov University, Kyiv, Ukraine, e-mail: marina.dielini@gmail.com

\title{
SPECIFICS OF MANAGING COMPETITIVENESS OF PRESENT-DAY UNIVERSITY ON PRINCIPLES OF SOCIAL RESPONSIBILITY
}

Purpose. Development of a management strategy for a domestic university on principles of social responsibility for raising its competitiveness in the globalization and internationalization context of higher education.

Methodology. The use of a dialectical method, system, structural-functional and institutional approaches as well as analysis, synthetic, comparison and expert evaluation techniques allows identifying a structure and functions of social responsibility of a university and a mechanism for its implementation in the internal and external environment.

Findings. Today's reality demands from a university to play a key role in the development of human capital assets and dissemination of social responsibility values in society, which is possible in case of improving university's competitiveness in the globalization and internationalization context of higher education. The authors of the article used their own administrative experience and knowledge in designing a strategy for raising competitiveness of a university as a socially responsible organization. They developed a mechanism for implementation of the above strategy through a university's social responsibility structure with the help of a strategically focused internal audit conducted in a university management system. It is proved that this strategy can be implemented through corporate culture of a university by inculcating social responsibility values in participants of the educational process.

Originality. To raise competitiveness of a university in the context of global challenges, its management strategy was developed on principles of social responsibility, which can be implemented through corporate culture by cultivating responsibility values in participants of the educational process. An authorial approach is proposed for setting internal audit objectives, based on identification and grouping of interests of the main groups of parties involved, their grouping and comparative analysis made with allowance for their interests and ways of influencing the university development. Some functional areas of an internal audit and its implementation algorithm are pointed out with consideration for operational specifics of a higher educational institution.

Practical value. The use of obtained results in educational and managerial practices allows creating a model of social responsibility of a university and outlining its implementation directions; developing and introducing a control mechanism for implementation of social responsibility actions; examining the development level of university corporate culture and proposing ways of its further development, aimed at raising competitiveness of higher educational institutions in the globalization context.

Keywords: social responsibility, university, competitiveness, social organization, corporate culture

Introduction. A new look at the University mission, its role in the human resources formation and its communicative function between education and entrepreneurship, is nowadays relevant and urgent. Social responsibility appears as the tool of the University's competitiveness and effectiveness increase, both inside the country and abroad [1]. Using the responsibility principle leads to the improvement of students, university staff and society wellness improvement.

Analysis of the recent research. To evaluate modern university competitiveness effectively, it is necessary to consider the social responsibility in several dimensions: philosophical, sociological, legal and economic.

In the field of History of Philosophy (Plato, Aristotle, Democritus, T.Hobbes, J.Locke, Baron d'Holbach, I. Kant, K. Marx, E. Fromm, H. Jonas, and others) the responsibility is considered in two ways. On the one hand, it is interpreted as closely correlated with a certain

(C) Aleksandrova O., Batchenko L., Dielini M., Lavryk U., 2018 social and cultural period and its prevalent values. On the other hand, its interpretation concerns the social limitation of the human freedom by the stereotypes and duties.

The sociological dimension of the responsibility is connected with comprehending the essence of the social hierarchy, its manifestation in the social interaction and personal actions (G. Marcuse, P. Sorokin, G. Spencer, A. Seligmen, A. Toffler, W. White, W. Warner, F. Fukuyama, and others).

Juridical responsibility appears as the coercion or encouragement from the state (D. Bernstein, S. Alekseev, L. Kalenichenko, Ye. Manuilov, and others).

Within the economics, the social responsibility appears as a combination of philosophical, sociological, and juridical aspects. It targets to persuade "business" to follow its obligations towards employees, the state, and society. The purpose of the business's social responsibility is the life improvement on both, micro (workers) and macro (society) levels and following of ethical norms 
and ecological imperative (M. Friedman, E. Epstein, F. Tuzzolino, B.Armandi, K. Trotman, G. Bradley, Archie B. Carroll, W. M. Evan, R. E. Freeman, E. Garriga, D. Mele, M. S. Schwartz, A. B. Carroll, Michael E. Porter and Mark R. Kramer, Patricia H. Werhane, and others).

Unsolved aspects of the problem. Considering the University as a social institution [2], whose main purpose is a high-quality education service delivered to the students, it is necessary to highlight an important aspect of a problem that requires a further study. Resolving and improving this aspect will contribute to the development of a perspective strategy of University competitiveness management. We mean the analysis of the achievements and limitations of corporate social responsibility in the modern world, which has two following components:

1. Definition of principles of corporate social responsibility in conditions of internal and external socially-responsible activity.

2. Justification of the benefits of the corporate social responsibility implementation into the institutions' activities.

The following principles of corporate social responsibility are pointed out: a) provision of consumers' needs according to the quality standards; b) compliance with the requirements of the legislation and mandatory implementation of partnership agreements; c) fair compe- tition; d) compliance with generally accepted ethical standards; e) counteraction to corruption and legalization of informal (shadow) incomes; f) gender equality; g) the unity of economic development and social prosperity; h) rational use of available resources and the efficiency of capital creating (economic, human, social, and others). For example, inquiries by O. Ye. Babina and A.A. Komarova [3]; I.S. Bila and N. V. Krasman [4], and others.

In other words, the principles of corporate social responsibility target a compliance with norms of behaviour and mandatory human rights, compliance with third parties interests and ethical behaviour.

Evtushenko V. and Shuba T. distinguish between internal and external socially-responsible activities (Table 1) [5].

Compliance with the principle of responsibility in the practical sphere requires taking into consideration the interests of stakeholders, who play a leading role in creating a social responsibility system in modern Ukrainian society [6]. For this reason, in order to determine the organization's main strategic objectives, it is necessary to investigate and structure the main expectations of stakeholders, taking into account their interaction, influence and significance. A comparative analysis of various types of stakeholders, their interests and ways of influencing the organization is presented in Table 2.

Table 1

Internal and external socially-responsible activities [5]

\begin{tabular}{|c|c|}
\hline \multicolumn{2}{|c|}{ Socially-responsible activity } \\
\hline Internal & External \\
\hline $\begin{array}{l}\text { staff support (career education, career motivation, career } \\
\text { development) }\end{array}$ & compliance with obligations to business partners \\
\hline $\begin{array}{l}\text { selection of capable employees, creation of conditions for } \\
\text { optimal realization of their talents, search of methods for } \\
\text { encouragement and maintenance in the management of } \\
\text { gifted personnel }\end{array}$ & transparency of accounting, regular and fair payment of taxes \\
\hline $\begin{array}{l}\text { stimulating the sense of employees social-safety by } \\
\text { establishing the conditions for their social security }\end{array}$ & compliance with the national and international law \\
\hline occupation safety and occupation hygiene & $\begin{array}{l}\text { transparent transmission of information, transparency in } \\
\text { communication with governmental bodies and mass media }\end{array}$ \\
\hline $\begin{array}{l}\text { creation and implementation of staff healthcare events, } \\
\text { providing employees' health development }\end{array}$ & $\begin{array}{l}\text { compliance with the production quality standards, provision of } \\
\text { qualified services for consumers }\end{array}$ \\
\hline $\begin{array}{l}\text { the motivation of employees to be responsible for their } \\
\text { duties, stability in paying salaries }\end{array}$ & civil society development and social initiatives facilitation \\
\hline $\begin{array}{l}\text { appropriate conditions for physical and mental rehabilitation } \\
\text { of staff, increasing of quality of human resources }\end{array}$ & $\begin{array}{l}\text { improvement of the environmental conditions, rational } \\
\text { consumption of natural resources, assistance to the health } \\
\text { rehabilitation of the population }\end{array}$ \\
\hline stimulation of the internal management interaction & $\begin{array}{l}\text { partnership with local governmental bodies, business and state } \\
\text { government for resolving the local communities problems }\end{array}$ \\
\hline $\begin{array}{l}\text { implementation of democratic principles in enterprise } \\
\text { management by involving employees in decision-making on } \\
\text { companies management }\end{array}$ & charity and patronage \\
\hline staff-friendly management & volunteering \\
\hline $\begin{array}{l}\text { creating the programs for socially-responsible enterprise } \\
\text { management }\end{array}$ & socially oriented, ethical and charity marketing \\
\hline
\end{tabular}




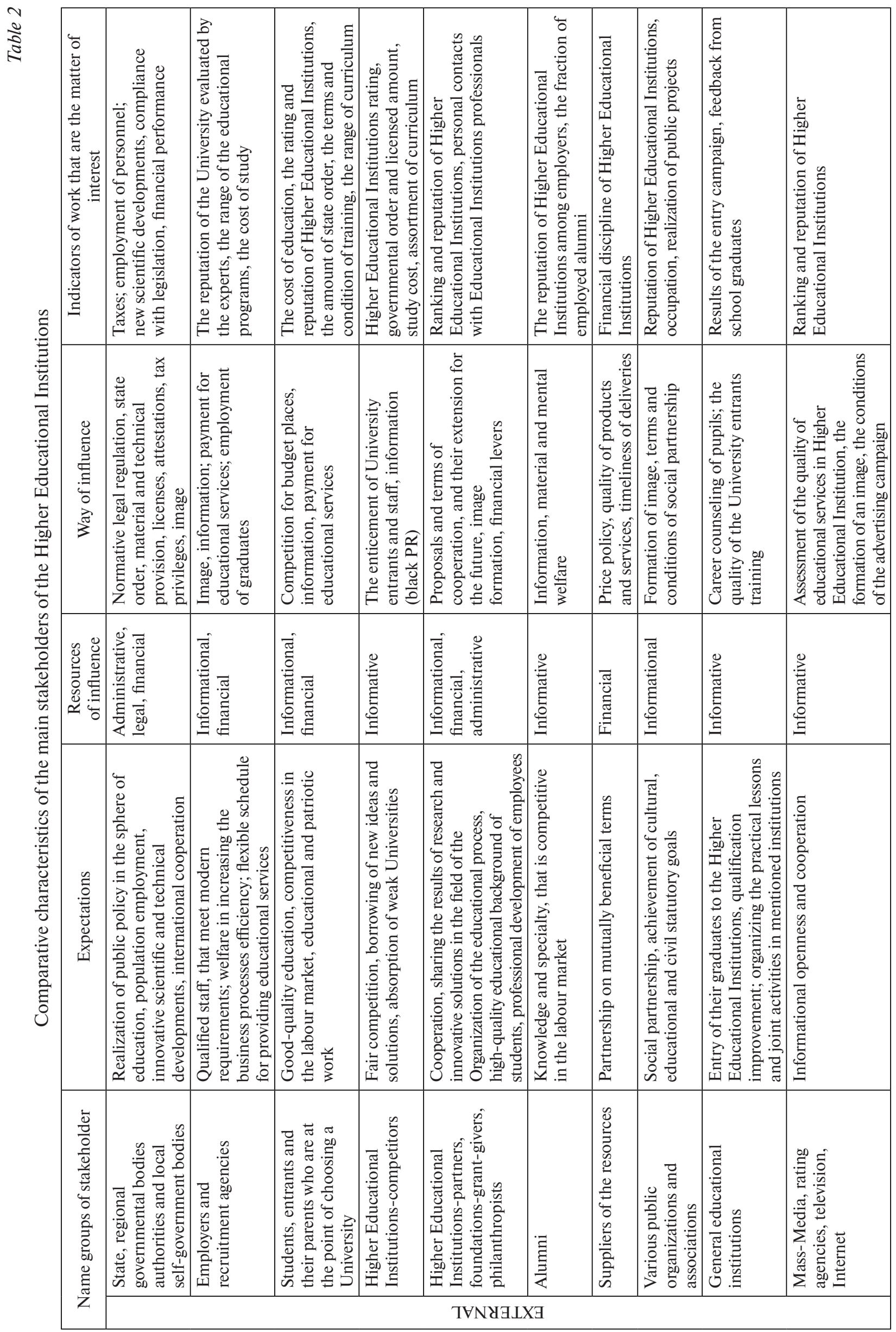




\begin{tabular}{|c|c|c|c|}
\hline 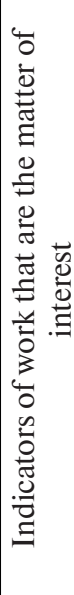 & 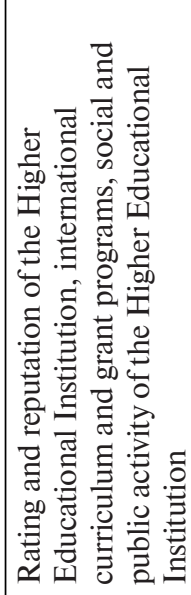 & 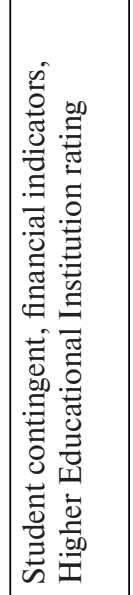 & 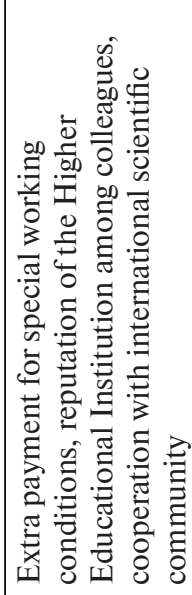 \\
\hline 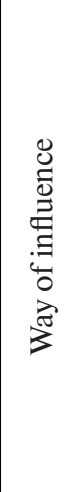 & 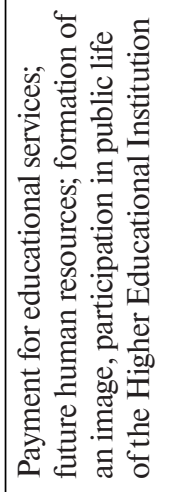 & 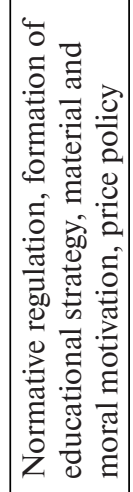 & 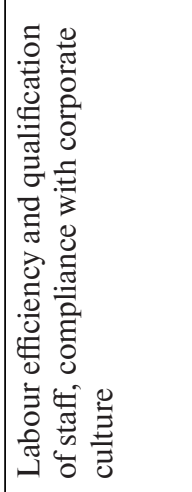 \\
\hline 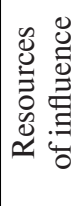 & 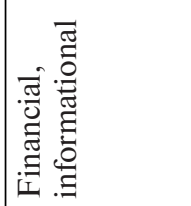 & 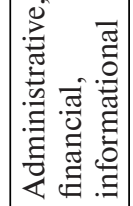 & 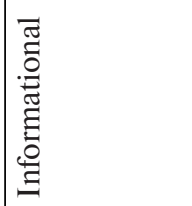 \\
\hline 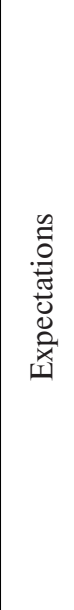 & 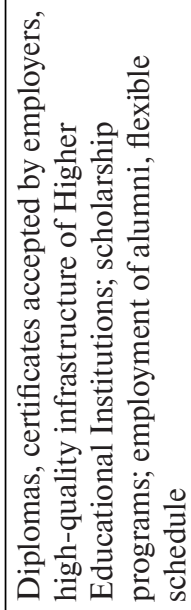 & 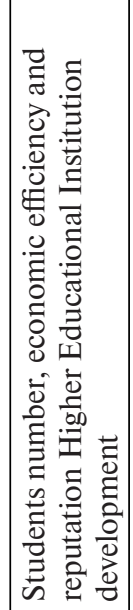 & 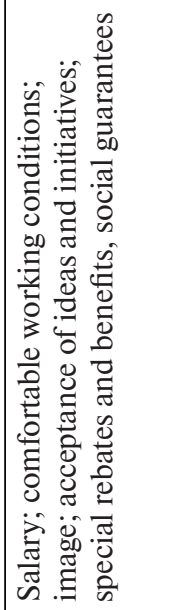 \\
\hline 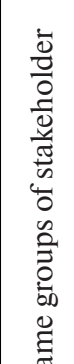 & 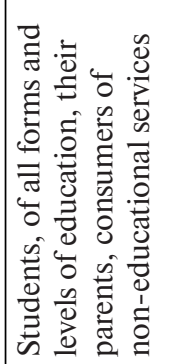 & 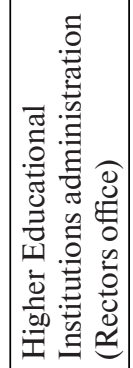 & 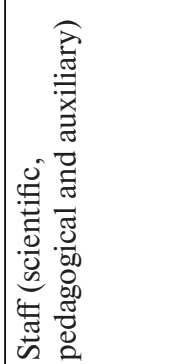 \\
\hline & \multicolumn{3}{|c|}{ TVNYGINI } \\
\hline
\end{tabular}


There are a lot of advantages of corporate social responsibility implementation into the institutions' activity. They are being discovered by scholars because of some controversial issues.

The following benefits can be pointed out: the longterm prospects, favourable for business; moral and ethical obligations; formation of good business reputation; improvement of the environment; reduction of state regulation; the balance of responsibility and power; increase in income of the enterprise owners (shareholders); availability of resources; social forecasting, targeted on the prediction of problems, but not on the elimination of their aftermath [7].

Consequently, the implementation of corporate socially-responsible practices has many advantages for the organisation: the micro-climate of the organization improves, the problem of the fluidity of highly-qualified staff is resolved, the organization's efficiency improves, the image improves, relations with partners, customers and suppliers are being well-established. The implementation of social responsibility makes a positive impact on the performance of the organization, despite the fact of necessary expenses.

Unfortunately, the corporate social responsibility in Ukraine has not become a part of strategic management yet. Only some organizations have a defined strategy of social responsibility. The formation of separate units has not started; there is no mechanism for monitoring the implementation of social responsibility. Ukraine has not formed a national model of social responsibility of business and governmental organizations yet. For example, the authors of the joint Ukrainian-Polish project [8] mentioned this fact. Particularly, if we compare the development of this model in neighbouring states, for example in Slovakia [9], or Poland [10].

Objectives of the article. In order to improve the performance of higher education, we propose a strategy of University management based on the principles of social responsibility. This strategy targets University competitiveness increase in the situation of globalization and internationalization of higher education.

Methods. To determine the structure and functions of the social responsibility of the University and the mechanism of its implementation, we use the following methods: the dialectical method, systemic, structural, functional and institutional approaches, as well as methods of analysis, synthesis, comparison and expert evaluation.

Presentation of the main research. For the successful implementation of the strategy of University competitiveness increase which is based on the principles of social responsibility, it is inevitable to conduct an internal audit of the system of University management. This audit must be held in the following areas:

1. The audit of the development strategy: audit of priorities, goals, objectives of development, principles and key values of an educational institution, assessment of the environment and analysis of the suitability of the needs and facilities of the institution to the requirements of the environment.

2. The audit of the educational process: audit of the compliance of the "roadmap" of the quality of the edu- cational process with the strategic objectives of the educational institution, monitoring and analysis of the results of the implementation of the "roadmap", audit of the system of technical, normative and methodological supply of the educational process.

3. Management audit: audit of the effectiveness of functional responsibilities share between subdivisions and employees; audit of the quality of the organizational structure; audit of structuring and efficiency of management processes; audit of technical and documentary management processes.

4. Audit of property: audit of availability, business operations and valuation of fixed and working capital.

5. Operational audit: audit of curriculum for compliance with regulatory requirements and labour market requirements.

6. Audit of intangible assets: intangible assets in the field of marketing, technology, creative and scientific activities, data processing and formation of a student contingent base, contracts and agreements related to human resources and the concept of "goodwill".

7. HR-audit: staff (dynamics for a certain period in terms of academic degrees, scientific degrees, honorary titles, age group dynamics, individual prominent achievements, and others); foreign-language, and especially English-speaking professionals (quantitative and qualitative dynamics for the particular period, readiness to provide English/foreign-language specialized curriculum, international certification); the availability of specialists-practitioners (what has changed in the training with the involvement of practitioners, the assistance for alumni employment, joint projects with the University); potential increase in human resources (thesis defence, gaining the scientific degrees and honorary titles for the particular period, internal system of professional development, international internship during the period, job promotion, management team-building); students (dynamics of the contingent, indicators of the average score at the enrolment, transformation in self-government, student initiatives); alumni (employment).

8. Marketing audit: marketing policy, pricing policy, advertising, research on the labour market, dynamics of brand recognition, indicators of partnership interaction of the University, specificity of promotion of the University brand.

9. Marketing audit: marketing policy, pricing policy, advertising, research of the labour market, dynamics of brand recognition, indicators of partnership interaction of the University, specificity of promotion of the University brand.

10. Audit of accounting and financial reporting.

11. Juridical audit: compliance with legislative requirements.

The algorithm of the internal audit of the Higher Educational Institution is depicted in detail by the Figure.

Dealing with all the components of the audit it is necessary to take into account the unmet needs and requests as well as the strategic vision of modernization and growth for the next period of development.

The necessary condition for University development strategy is a corporate culture that determines the pecu- 


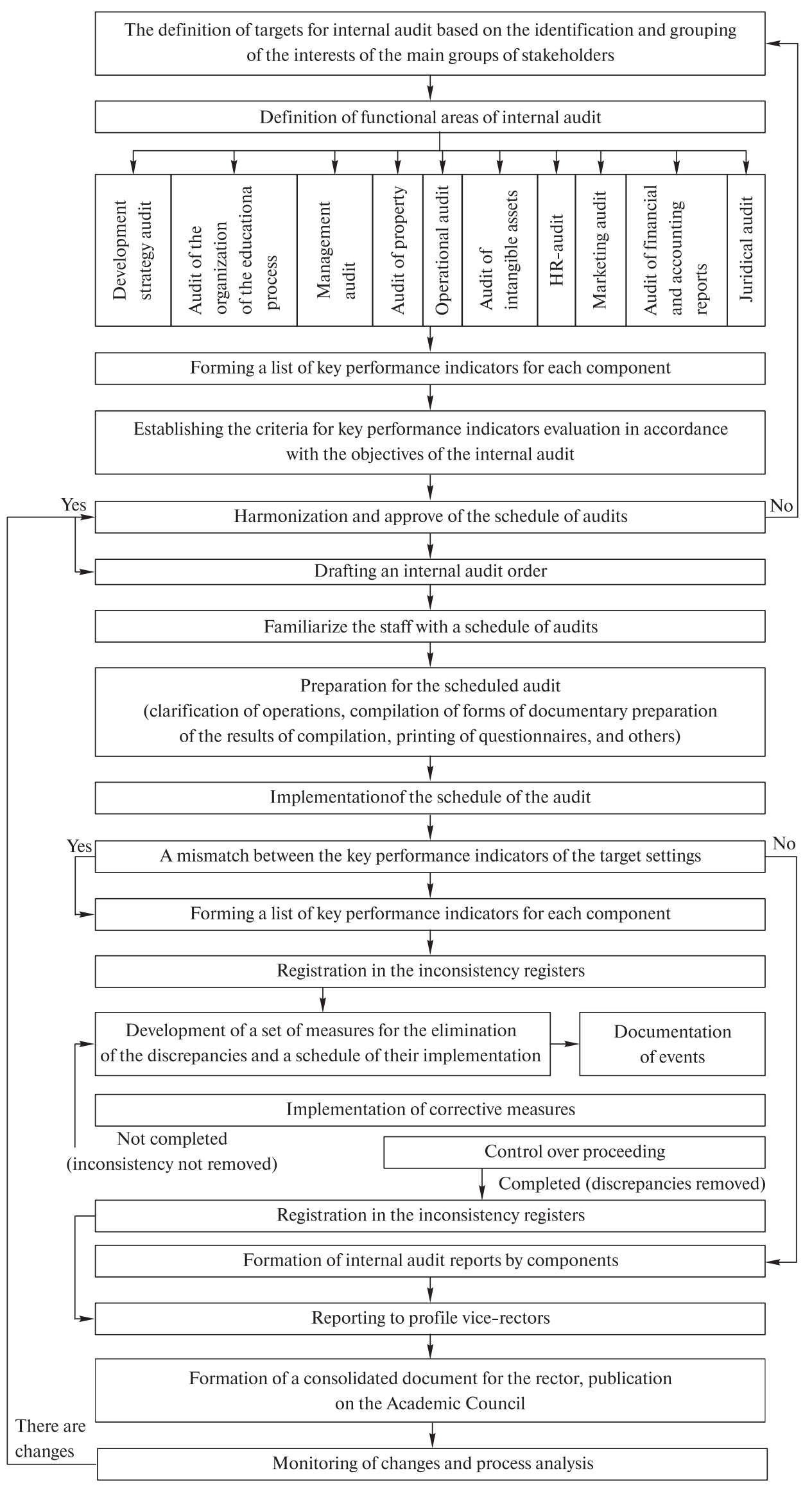

Fig. The algorithm of the internal audit of the Higher Educational Institution 
liarities of the internal values architectonics (mission, vision, values) as well as the specifics of the human resources increase (the foundation for further institutional development and development of the university) [11]. A particular type of corporate culture determines the specifics of the social responsibility of the University. Presently, the most viable model of responsibility draws the University as a "social activist". This model assumes that organizations are responsible to the whole society. Managers at the same time must be social and moral leaders in society. The social activity model is based on ethics [12].

In our opinion, the strategy of the University competitiveness increasing can be realized through its corporate culture. We mean inculcating the value of social responsibility to the participants of the educational process. To do this, it is necessary to classify a particular type of culture, for example, according to the directions proposed by the G. Hofstede [13]: individualism/collectivism, masculinity/femininity, short-term/long-term orientation, authoritative distance, avoidance of uncertainty. The next step is the implementation of the declared strategy through its structure: the surface level is an external manifestation of corporate culture; subsurface level is ethics, morality, regulations of behaviour, comprehended and admitted by the organization members; deep level appears as unconscious non-evidenced acceptance of the fundamental values of the organization [14]. The corporate culture inside the University has a common value for all participants of the educational process. Due to the person's aspirations to achieve a confidence and stability in everyday life, the corporate culture, dealing with corresponding values, forms the attitude of the individual to the outer world and appears as the guideline for determining the sense of human activity, its attitude to the society and nature. Possibilities of cultural influence on the person are described by V. Fatkhutdinov and O. Bazaluk [15].

Conclusions and recommendations for further research. The present conditions persuade Universities to play a leading role in the formation of human resources as well as in the dissemination of the values of social responsibility in society. This seems to be possible on the basis of increasing its own competitiveness in the conditions of globalization and internationalization of higher education. The authors of the article used their own administrative experience and knowledge developing the strategy of increasing the competitiveness of the University as a socially responsible organization. A mechanism for implementing this strategy was developed through the structure of the social responsibility of the University, through the implementation of a strategically-oriented internal audit in the university management system. It is proved that mentioned strategy can be realized through the corporate culture of the University. We mean inculcating the value of social responsibility to the participants of the educational process.

The corporate culture inside the University has a common value for all participants of the educational process. Due to the person's aspirations to achieve a confidence and stability in everyday life, the corporate culture, dealing with corresponding values, forms the attitude of the individual to the outer world and appears as the guideline for determining the sense of human activity, its attitude to the society and nature.

The following topics require further research: developing a mechanism for monitoring of the implementation of social responsibility; creation of the theoretical model of social responsibility of national business and state organizations and development of ways of its practical implementation; research on the corporate culture of the modern University as a factor of its institutional formation and development in the conditions of global challenges.

\section{References.}

1. Aleksandrova, O.S., 2015. Corporate Culture as a Factor in the Formation and Development of a Modern University. Neperervna profesiyna osvita: teoriya i praktyka, 3, pp. 21-26.

2. Chepak, V. V., 2013. University as a Social Organization: Transformation in the Conditions of Globalization. Visnyk Kharkivs'koho natsional'noho universytetu imeni V.N. Karazina. Seriya Sotsiolohichni doslidzhennya suchasnoho suspil'stva: metodolohiya, teoriya, metody, 1045, pp. 181-185.

3. Babina, O. Ye. and Komarova, A. A., 2014. Mechanism for Raising the Level of Socially Responsible Activity of Ukrainian Enterprises. Biznes Inform, 12, pp. 69-74.

4. Bila, I. S. and Krasman, N. V., 2017. Social Responsibility of Business: Theoretical Aspects and Practical Realization in the Economy of Ukraine. Skhidna Yevropa: ekonomika, biznes ta upravlinnya, 5(10), pp. 3-7.

5. Evtushenko, V.A. and Shuba, T. P., 2016. Strategy of Institutionalization of Social Responsibility in the Organization. Visnyk Odes'koho natsional'noho universytetu. Seriya : Ekonomika, 21(1), pp. 85-91.

6. Fursa, M.V., 2014. Social Responsibility of the Enterprise: Theoretical and Methodological Problems of Formation. Demokratychne vryaduvannya, 14. Available at: <http://nbuv.gov.ua/UJRN/DeVr_2014_14_26> [Accessed 10 January 2017].

7. Bukharina, L. M. and Suchkov, A. V., 2014. Use of Social Responsibility of Business to Create a Positive Image of the Enterprise. Ekonomika $i$ orhanizatsiya upravlinnya, 1-2, pp. 48-53.

8. Rudenko, S., Sapenko, R., Bazaluk, O. and Tytarenko, V., 2018. Management Features of International Educational Projects Between Universities of Poland and Ukraine. Naukovyi Visnyk Natsionalnoho Hirnychoho Universytetu, 2, pp. 142-147. DOI: 10.29202/nvngu/ 2018-2/21.

9. Goda, S. and Ušiak, J., 2016. What is the Threat Perception of the Slovak Republic? Central European Journal of International and Security Studies, 10(1/2016), pp. 61-87. 10. Pstuszek, A., 2018. The Social Potential Of the Polish Art in the Transformation Period. Future Human Image, 9, pp. 82-91. DOI: 10.29202/fhi/9/8.

11. Bazaluk, O., 2017. Plato's and Isocrates' Traditions in the Development of Educational Theories in the History of Culture. Annals of the University of Craiova Philosophy Series, 40(2), pp. 5-18. 
12. Repaul Kanji and Rajat Agrawal, 2016. Models of Corporate Social Responsibility: Comparison, Evolution and Convergence. IM Kozhikode Society \& Management Review, 5(2), pp. 141-155. Available at: $<$ http://journals. sagepub.com/doi/pdf/10.1177/2277975216634478> [Accessed 29 April 2017].

13. Hofstede, G., 2011. Dimensionalizing Cultures: The Hofstede Model in Context. Online Readings in Psychology and Culture, 2(1). Available at: <https:// doi.org/10.9707/2307-0919.1014> [Accessed 30 April 2017].

14. Edgar H. Schein, 2015. Organization Psychology Then and Now: Some Observations. Annual Review of Organizational Psychology and Organizational Behavior, 2, pp. 1-19. Available at: <https://www.annualreviews. org/doi/full/10.1146/annurev-orgpsych-032414111449\#_i4> [Accessed 01 May 2017].

15. Fatkhutdinov, V. and Bazaluk, O., 2018. The Importance of the Brain Neuro-Programming Technologies in National and Regional Security Strategies. Philosophy and Cosmology, 20, pp. 74-82. DOI: 10.29202/philcosm/20/6.

\section{Особливості управління конкурентоспроможністю сучасного університету на засадах соціальної відповідальності}

\author{
О. С. Александрова ${ }^{1}$, Л. В. Батченко ${ }^{2}$ М. М. Дєліні ${ }^{3}$, \\ У. В. Лаврик ${ }^{1}$
}

1 - Київський університет імені Бориса Грінченка, м. Київ, Україна, e-mail: olena.aleksandrova@yahoo.com; u.lavryk@kubg.edu.ua

2 - Київський національний університет культури і мистецтв, м. Київ, Україна, e-mail: ludavic@meta.ua

3 - Національний педагогічний університет імені М.П.Драгоманова, м. Київ, Україна, e-mail: marina. dielini@gmail.com

Мета. Розробка стратегії управління вітчизняним університетом на засадах соціальної відповідальності задля підвищення його конкурентоспроможності в умовах глобалізації та інтернаціоналізації вищої освіти.

Методика. Використання діалектичного методу, системного, структурно-функціонального, інституційного підходів, а також методів аналізу, синтезу, порівняння, експертної оцінки дає можливість визначитися зі структурою й функціями соціальної відповідальності університету та механізмом іiі peaлізації у внутрішньому й зовнішньому середовищі.

Результати. Реалії сьогодення вимагають від університету відігравати провідну роль у формуванні людського капіталу, розповсюдженні цінностей соціальної відповідальності в суспільстві, що можливо на засадах підвищення власної конкурентоспроможності в умовах глобалізації та інтернаціоналізації вищої освіти. Автори статті застосували власний адміністративний досвід і знання при розробці стратегії підвищення конкурентоспроможності університету як соціально відповідальної організа- ції. Був розроблений механізм реалізації цієї стратегії через структуру соціальної відповідальності університету, за допомогою здійснення стратегічно-орієнтованого внутрішнього аудиту в системі управління університетом. Доведено, що відповідну стратегію можна втілити через корпоративну культуру університету засобами прищеплення цінності соціальної відповідальності учасникам освітнього процесу.

Наукова новизна. Розроблена стратегія управління університетом на засадах соціальної відповідальності, яку можна втілити через корпоративну культуру засобами культивування цінності відповідальності учасникам освітнього процесу, з метою підвищення конкурентоспроможності університету в умовах глобальних викликів. Запропоновано авторський підхід визначення цільових установок внутрішнього аудиту на основі ідентифікації та групування інтересів основних груп зацікавлених сторін, проведено їх групування й порівняльний аналіз з позиції їх інтересів і способів впливу на розвиток університету. Виділені функціональні напрями внутрішнього аудиту та алгоритм його реалізації 3 урахуванням специфіки діяльності закладу вищої освіти.

Практична значимість. Використання одержаних результатів в освітній і управлінській практиці дозволяє створити модель соціальної відповідальності університету та окреслити напрями їі реалізації; розробити й втілити механізм контролю впровадження заходів із соціальної відповідальності; дослідити рівень становлення корпоративної культури університетів і запропонувати шляхи ії подальшого розвитку з метою підвищення конкурентоздатності закладів вищої освіти в умовах глобалізації.

Ключові слова: соціальна відповідальність, університет, конкурентоспроможність, соціальна організація, корпоративна культура

\section{Особенности управления конкурентоспособностью современного университета на принципах социальной ответственности}

\author{
Е. С. Александрова ${ }^{1}$, Л. В. Батченко ${ }^{2}$, М. М. Делини ${ }^{3}$, \\ У. В. Лаврик ${ }^{1}$
}

1 - Киевский университет имени Бориса Гринченко, г. Киев, Украина, e-mail: olena.aleksandrova@yahoo.com; u.lavryk@kubg.edu.ua

2 - Киевский национальный университет культуры и искусств, г. Киев, Украина, e-mail: ludavic@meta.ua 3 - Национальный педагогический университет имени М.П.Драгоманова, г. Киев, Украина, e-mail: marina. dielini@gmail.com

Цель. Разработка стратегии управления отечественным университетом на основе социальной ответственности для повышения его конкурентоспособности в условиях глобализации и интернационализации высшего образования. 
Методика. Использование диалектического метода, системного, структурно-функционального, институционального подходов, а также методов анализа, синтеза, сравнения, экспертной оценки дает возможность определиться со структурой и функциями социальной ответственности университета и механизмом ее реализации во внутренней и внешней среде.

Результаты. Реалии сегодняшнего дня требуют от университета играть ведущую роль в формировании человеческого капитала, распространении ценностей социальной ответственности в обществе, что возможно на основе повышения собственной конкурентоспособности в условиях глобализации и интернационализации высшего образования. Авторы статьи использовали собственный административный опыт и знания при разработке стратегии повышения конкурентоспособности университета как социально ответственной организации. Был разработан механизм реализации этой стратегии через структуру социальной ответственности университета, посредством осуществления стратегически ориентированного внутреннего аудита в системе управления университетом. Доказано, что соответствующую стратегию можно воплотить через корпоративную культуру университета средствами привития ценности социальной ответственности участникам образовательного процесса.

Научная новизна. Разработана стратегия управления университетом на основе социальной ответственности, которую можно воплотить через кор- поративную культуру средствами культивирования ценности ответственности участникам образовательного процесса, с целью повышения конкурентоспособности университета в условиях глобальных вызовов. Предложен авторский подход определения целевых установок внутреннего аудита на основе идентификации и группировки интересов основных групп заинтересованных сторон, проведена их группировка и сравнительный анализ с позиции их интересов и способов воздействия на развитие университета. Выделены функциональные направления внутреннего аудита и алгоритм его реализации с учетом специфики деятельности учреждения высшего образования.

Практическая значимость. Использование полученных результатов в образовательной и управленческой практике позволяет создать модель социальной ответственности университета и определить направления ее реализации; разработать и воплотить механизм контроля внедрения мероприятий по социальной ответственности; исследовать уровень становления корпоративной культуры университетов и предложить пути дальнейшего развития с целью повышения конкурентоспособности высших учебных заведений в условиях глобализации.

Ключевые слова: социальная ответственность, университет, конкурентоспособность, социальная организация, корпоративная культура

Рекомендовано до публікації докт. екон. наук I. С. Грозним. Дата надходження рукопису 17.05.17. 